\title{
GYULA HAJNÓCZI, THE INSTRUCTOR AND TEACHER
}

\author{
GYULA ISTVÁNFI \\ CSc, professor emeritus. Department of History of Architecture and Monument Preservation, \\ BME K II. 82, Múegyetem rkp. 3, H-1111 Budapest, Hungary. \\ Phone: (+36-1) 463-1330. E-mail: gyula.istvanfi@gmail.com
}

\begin{abstract}
On the centenary of Gyula Hajnóczi's birth, we commemorate the architect, the archaeologist, the teacher, the writer, the scientist, as well as the man and our colleague in the framework of a conference. This time, in memory of the teacher of architecture history and our colleague at the department, his teachers are introduced from the time of the start of his career, from life and regime changing times. Hajnóczi's specialization, i.e. choosing the history of ancient architecture, took a definite direction from the very beginning of his practice. In addition to his certification in architecture, he soon obtained his diploma in archaeology, then achieved scientific titles and professional results. As an instructor, he conveyed the introductory knowledge of the architect profession, architectural drawing, and the history of the profession to the students on the basis of well-developed principles, performed in various ways. $\mathrm{He}$ followed the stages of architectural survey, technical drawing and graphic elaboration. His lectures on ancient architecture - Prehistoric Asia, Egypt, Hellas, Rome - were always performed according to an elaborated system, in a logical structure and always in an enjoyable form. His maxim was that architecture was the science of continuous building.
\end{abstract}

Keywords: Gyula Hajnóczi, $100^{\text {th }}$ anniversary, architect, ancient archaeologist, architectural historian, conservationist

For me, speaking of Gyula Hajnóczi is a remembrance of a lifelong era. I met him, a teacher of Antiquity, in 1958 as a first-year architecture student, and a month and a half before his death we were sitting at a table in front of my weekend house in Nagymaros, enjoying the summer sun. This is thirty-eight years, at the beginning of which he was 38 years old. After defending my diploma - while working for two more years in a workplace making me flee and returning to the University as a lecturer - I became an assistant professor at the Department of History of Architecture in 1964. At that time, the teaching of historic periods was divided between the assistant lecturers in the department, and I went to Gyula Hajnóczi, who taught the subject of Antiquity. This is the beginning of our thirty-two-year collaboration as a duet, in the form of Gyula the Big and Gyula the Small. Initially six, later five days a week, working together from morning to night at the department or on-site work (Fig. 1).

Looking back on our youth, I cannot leave the look of Gyula Hajnóczi as a man without a word. He was a well-dressed, tall, handsome man. Once, when I was a student, I went to the department with some extra work, and one of my girl class-

\# This work was supported by the National Cultural Fund of Hungary (NKA) under Grant Number $101108 / 547$.

(C) 2020 The Author 


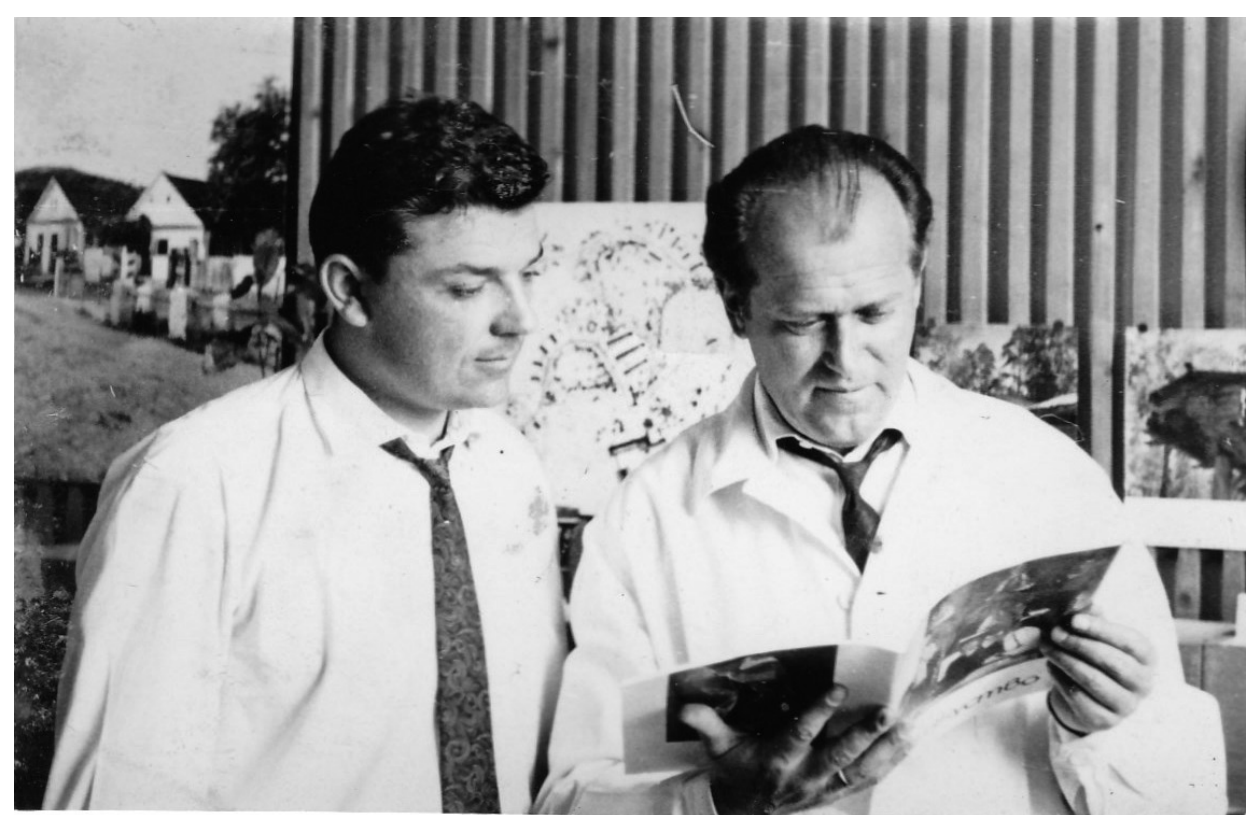

Figure 1. The author with Gyula Hajnóczi at the Department in 1964.

mates asked me to let her accompany me just to see Hajnóczi. Others observed during the lecture that his watch strap (black or brown) matched the suit he was wearing. He was an elegant phenomenon even if he wore a white cloak provided by the university as a work suit.

When speaking of an instructor, it is worth mentioning who his teachers and professors were. His generation had two events to learn from: the Treaty of Trianon and World War II. This generation has learned to tolerate, to listen, not to be surprised, to appreciate. He once told me his short philosophy of life: Aristocratic Democracy. Take note of the world and watch it from the right distance. This is how the $20^{\text {th }}$ century could be survived in an honest way.

After an attempt at college and performing military service, in 1946, he enrolled for the second time in the Department of Architecture of the József Nádor Technical University. The teachers of that time were: Pál Csonka, Iván Kotsis, Károly Arvé, Alfréd Bardon, and two new instructors: Tibor Kiss and Károly Weichinger. The Department of Ancient and Early Modern Architecture was headed by Lóránd Friedrich, the Department of Medieval Architecture by Jenö Rados. They were his first teachers. The subjects were only slightly modified compared to the pre-war curriculum. However, in 1948/49, after the political turn the curriculum changed significantly. After Friedrich's death, György Kardos became the head of the Department of Ancient and Early Modern Architecture, and Máté Major, joining the university in 1949, founded the Department of General Architecture, replacing the former Department of Ancient Architecture. After graduation (1950), Gyula Hajnóczi 
joined the department of Jenö Rados, and later the department of Máté Major. In 1958, he graduated from the Faculty of Arts with a degree in Archaeology, thus becoming a full-fledged master of the subject of Ancient Architecture.

The predecessors of the Department of History of Architecture were not real historical departments. The $19^{\text {th }}$ century departments taught architectural styles, from 1887 the subjects covered ancient, medieval and early modern (Renaissance and Baroque) styles. Until 1944, the departments were called Ancient Architecture, Medieval Architecture and Early Modern Architecture. That is, these departments were historical only in the sense that they were divided into the great periods of history. Of course, the lectures included issues related to the history, nature, choice of materials, etc. of the discussed countries, but the specific aim was to teach building structures and morphological features of the great eras. Therefore, the form of education was mostly drawing. The task was to accurately copy the architectural drawings - floor plans, sections, façades and detail forms - rescaled on the basis of sample sheets. Then, based on this knowledge, students had to design smaller, later larger buildings in the given style. The latter task lost its significance in the 1940s, as the university already provided a separate design department and subject under the leadership of Iván Kotsis. From 1945, two new design departments were established with professors Tibor Kiss and Károly Weichinger. Between 1948 and 1956, epoch-making events took place at the University in the field of curriculum change, increasing the number of students and the appearance of new lecturers.

In the new system, the departments of history retained their divided structure, and this was the time when the subjects became courses that actually communicated historical knowledge, known as the history of architecture of the prehistoric communities, Antiquity, the Middle Ages, the Early Modern (Renaissance and Baroque), and the Modern Age. They basically followed the translation of the architectural volume of the Great Soviet Encyclopedia, in a Marxist embedding. The history of Hungarian architecture and art and the monument preservation have had their studies before. For many years, practical subjects meant copying well-proven historical morphological and architectural drawings. These practices had design benefits during the years of the Socialist-Realist style rule in the field of massing, façade formation, and the application of sections. By the time of the simplified Modern, a different kind of architectural educational benefit had to be articulated. An educational goal published in 1963 at the department was: "to provide professional literacy, architectural approach, professional history and aesthetic foundations. Develop advanced architectural drawing skills through architectural morphology during the workshops."

Gyula Hajnóczi's teaching activity began under such circumstances. Still stuck to the old custom, my first semester assignment of ancient architecture - as evidenced by my two surviving drawing sheets - was the floor plan and longitudinal section of an ancient Greek temple depicting the building layers in A3-sized painted pencil drawings and detailed drawings (Fig. 2-3). The processing was done in a weekly schedule of composition, technical drawing and outlining, supervised by the instructor. To understand the following, it is necessary to emphasize that from the 1960s the Faculty of Architecture was living in a fever of constant reforms. 

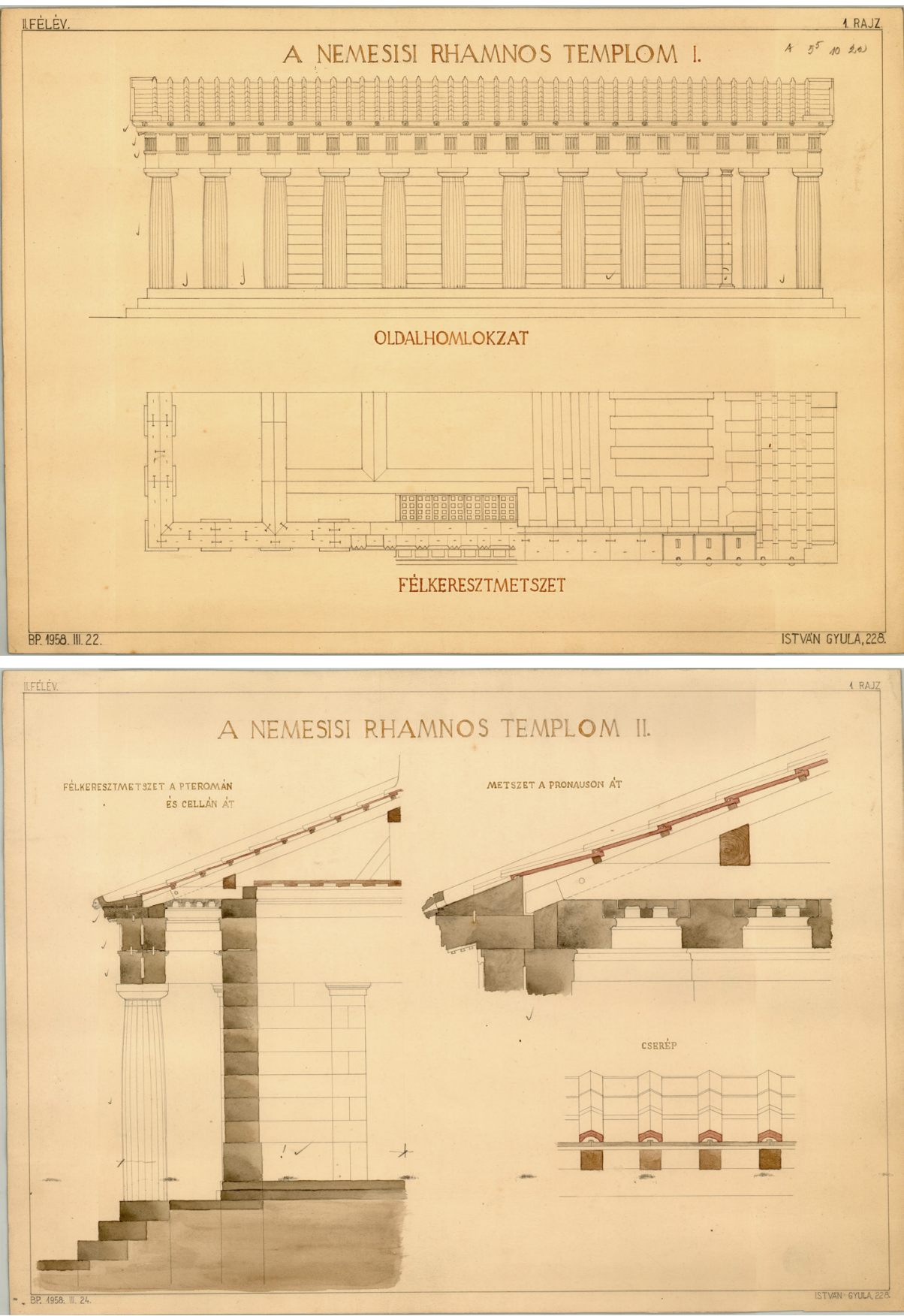

Figure 2-3. Student drawings by the author, 1958. 
In the spirit of the changes, Gyula Hajnóczi gave up the system of several-week-long drawing tasks, and since the practical aim of the subject was the development of drawing skills, he switched to the weekly task system. The students had to process the Greek Doric, Ionic, Corinthian and Roman Doric, Ionic, Corinthian, Composite column orders, on one A4 drawing sheet per week. Since the scale of the column orders was the module, and there were a number of detail drawings to be prepared quite precisely - dentil, palmettes, acanthus leaves, etc. - the requirement of practicing independent measurement and precise drawing skills, as well as the tight deadlines, forced the students to do conscientious work. The morphological tasks meant a lot of work, which Hajnóczi justified for us with such sayings that "drawing knowledge is power" or "architecture can only be learned by drawing". The assignments were classified with two marks: content and design. He had a saying about it: "in determining quality, the amount of work put into the creation matters". As a result of these requirements, architects graduating at the time were truly able to draw. This skill is untraceable on digital plans made today.

Fewer, but more expressive drawings and well-worded texts were created during a short-lived practical course called the Dictionary of Ancient Architecture, published in small A5 format booklets. Perhaps this assignment was the answer to student comments on Professor Hajnóczi using a lot of foreign words in his lectures. This was an obvious consequence, as in Greco-Roman architecture the building parts, sections and building types were named in Greek or Latin. In preparing the dictionary, the goal was also to specify the Hungarian equivalents, e.g. abacus $=$ fejlemez (flat slab on top of a column providing support). This method clearly succeeded in transferring knowledge with strong embedding.

A similar practical assignment with theoretical processing was when the correct floor plan of a certain building had to be drawn on A3 format drawing sheets, and then the structure (wall, column, pillar surface in the floor plan), surfaces, covered areas, semi-open surfaces and open (courtyard) spaces had to be marked in a similar drawing. After calculation, the proportions of the mentioned surfaces were marked in a building contour of the same size. With this, students, based on their calculations, were able to illustrate the quantities of materials typically used to create spaces in certain periods of Ancient architecture.

Architect teachers often draw during their lectures, for which they have a black board and chalk. When slide projection assisted lectures brought visual technology to the University, and the Department of Educational Technology installed a six-meter-wide screen in Lecture Hall 232, Gyula Hajnóczi experimented with a new method. In the last row of benches, he made a pulpit consisting of a desk surface and a bench. This way, renouncing the benefits of face-to-face lectures, he could draw the illustrations with the help of a projector from behind, and the students could draw synchronously by following his hand gesture. More precisely, this was only a theoretical possibility because no projector with the right brightness and adjustable focus could be purchased at that time. The pulpit remained, and widescreen projections could be made from there for years to come. 
The most suitable way to learn and teach architecture, history of architecture, architectural morphology is the architectural survey. Especially if the goal is to survey a historic, old building waiting to be captured, recorded or restored. There was a student task at the time of establishing a closer relationship with the Aquincum Museum; a tombstone had to be surveyed in the lapidary of the Museum, which had architectural details in addition to the figural ones. From the very beginning of our department's operation, this training has been one of the most popular methods for students. One of Gyula Hajnóczi's first works, also published in print, was the booklet entitled The Survey of Monuments. ${ }^{1}$ The book is still a basic work in the field of methodology, tools and techniques on the subject of manual and first instrumental (geodesy) surveys.

When the possibility of a two-week summer workshop on urban survey arose, the ancient morphological practical courses were immediately transformed into survey practice. It focused on the building parts, gates and gateways of the Eclectic buildings of Budapest, i.e. the existing and prevailing features of Classical architecture. Pedestals, columns, cornices, attics, or balusters could be found everywhere, and their survey and scale-based documentation was a good preparatory practice for the next summer urban survey works.

In the title of my recollection two terms are used: instructor and teacher. The instructor is a master who conveys professional knowledge, and the means of communication towards the student is practice, as it is called by school custom in our profession. After briefly introducing his drawing practice courses on the ancient history of architecture, I must mention the activity of Gyula Hajnóczi as a teacher. Above all, a teacher is the responsible leader of a subject or a major; a person determining the content and methods, and an oral lecturer speaking to a larger audience.

Gyula Hajnóczi gave lectures on the History of Ancient Architecture already when he was an assistant professor. I referred to the conditions prevailing at the Faculty of Architecture between 1948 and 1956: ideological dogmas, communist engineering training, etc., the obligatory application of the above-mentioned encyclopedia and the omission of previous works of architectural history. I believe that such circumstances motivated Gyula Hajnóczi to graduate from the Faculty of Arts, Eötvös Loránd University with a degree in Archeology (1958), to obtain a doctorate (1966), and then the Candidate of Technical Sciences qualification (1966). He was then ready to start writing The History of Architecture, Ancient Cultures textbook (1967) (the first volume in the series) with sufficient professional background knowledge. ${ }^{2}$ The book

\footnotetext{
${ }^{1}$ Müemlékfelmérés. [The Survey of Monuments] Építőipari Müszaki Egyetem Tudományos Közleményei 6. Budapest 1956. 1-69. Tables No. I-XXX. (Co-authors: Károly Ferenczy, Antal Horn, Zsigmond Laboda, Elemér Nagy, László Vargha)

${ }^{2}$ Az épitészet története. Ókor. [The History of Architecture, Ancient Cultures] Tankönyvkiadó, Budapest 1967. 462 p., 623 figures. I-V. editions until 1982; Az építészet története. Ókor I. Keleti és átmeneti kultúrák. [The History of Architecture, Ancient Cultures I - Oriental and Transitional Cultures] Tankönyvkiadó, Budapest 1991; Az épitészet története. Ókor II. A klasszikus kultúrák. [The History of Architecture, Ancient Cultures II - Classical Cultures] Tankönyvkiadó, Budapest 1991.
} 
is structured by introductory and concluding parts of each culture, forming the chapters of systematic knowledge. The geographical and natural features were followed by the characteristics of the economy and society. Then, added to the cultural, religious, and political information, the textbook outlined the emerging architectural developments in a two-column layout. This was followed by the presentation of place, culture - Near East, Egypt, Hellas, Rome - morality, literature, science, and art. The book summarized the tools (material, structure, technology) by presenting the orderly architectural technique, followed by the history of architecture itemized by residential houses, palaces, churches, public buildings, cities. Finally, it summarized the means of expression of the given architectural era, the phenomena of spatial formation, massing and façade design. Interestingly, the authors of textbooks on other periods - Byzantine, Romanesque, Gothic, Renaissance, and Baroque - written much later did not follow this structure. I not only learned thoroughly Ancient architecture by drawing and measuring the 337 figures in the book, but the biggest lesson for me was that a good teacher passes on knowledge to his student in an orderly way.

The quality of lectures given play an important role in the everyday judgment of teachers. No doubt, in the thirty-year period from 1960 to 1990, the lectures of Frigyes Pogány were famous for being captivating, spectacular and informative. I risk - the otherwise subjective opinion - that the second most attractive speaker was Gyula Hajnóczi. The structure of his lectures followed the textbook, so they were clear and concise. He used many foreign words in his vocabulary -i.e. the Latin form of structure, proportion, spatial, convergent, etc. - the understanding of which caused difficulty for vocational high school students of the era coming from many rural areas. At the same time, or precisely for this reason, there was something sublime, solemn in his lectures. He admitted that the Greek and Latin terms were intended to achieve just that effect. This was often true for his everyday speech as well, e.g. a pretty bikini girl at the excavation summer camp was a "well-proportioned student" for him.

Apropos, excavation summer camp. For several years from 1966, we were organizing excavation camps for architect students - Hungarian, Polish, Estonian, German, French and Yugoslav - in collaboration with Klára Póczy, the director of the Aquincum Museum. At that time, international students were rarely brought together. The pedagogical benefit was that after a day of excavation and hard physical work, the conversations, playing music and befriending by the evening campfire led to cultural recognitions. During this cultural exchange, the world opened up a little for students. It was then that Béla Halmos and Ferenc Sebö realized how unexplored and unknown Hungarian folk culture, music and dance were for young people. So, they left the profession for the sake of folk music and folk dance, in which field they achieved national success and prestigious results.

Gyula Hajnóczi was not a strict teacher, he was not one of the legendary rigorous university teachers. At the same time, he was looking for a precise way of examining student knowledge. The news of the new test-like exams came from the Medical University, as there were also problems with the time-consuming nature of mass 
examinations. We invented a fifty-question, three-answer-variation answer sheet with a perforated evaluation sheet, which method worked for years. First Hajnóczi corrected the tests himself, then left this work to me. Depending on the correct answer and the number of students, the result always showed a bell curve, and with the grade limit values taken at the characteristic points of the curve, an "objective" rating was achieved. These grades together with marks given on practice, and the possibility of oral exams provided the method of grading for years. ${ }^{3}$

In the 1970s, there was a generational change within the Faculty among the senior lecturers. At the time of the Department's institutionalization, between 1974 and 1986, Gyula Hajnóczi was the Deputy Director and the Head of the Department of the History of Architecture. In the period from 1978 to 1984, he was also an elected Vice Dean of Education. During these years, faculty education was carried out in a so-called sectoral system, divided to four sectors: constructor, architect, urban planner, and technologist. In principle, the division was made by pre-determined proportions, but was always overwritten by the students' preference. The $10 \%$ deviation of each curriculum by sectoral courses only nuanced the unified architect training, the difference was not indicated by the diploma. The organization of students' summer internship was also a problematic faculty topic. It included physical work after the first year, and office work after the second year. The students did not like any of them, and these practices were considered a necessary evil also by the Faculty leadership. Hajnóczi as the Vice Dean initiated the introduction of a two-week summer camp dealing with building survey and drawing practice in the historical center of small rural towns instead of the unpopular practical forms. From 1979 for 15 years, this city center survey was the Faculty's favorite summer camp, with the cheerful participation of not only the students but also the teachers of the history of architecture. The work resulted in the city-scale, street view survey of twenty city centers and building complexes, as well as complete documentation of many buildings.

I know that commemorating a man who once lived is always a compunction for posterity. Because twenty-five years, the time of one generation, is just enough for complete oblivion. But celebrating the birthday - which was April 6, postponed due to the pandemic - always carries optimism. And I also know - and this is my credo that what once existed, what is here now, and seems to fade away, does not pass without a trace. As Hajnóczi put it, 'architecture is the science of continuous construction.' 'To incorporate the creative abilities of the new generation into the centuries-long chain of builders, and to continue the intellectual and real constructions of our profession' was his Credo.

\footnotetext{
${ }^{3}$ Archaeological commemoration: Póczy, Klára: Hajnóczi Gyula emlékezete. [The memory of Gyula Hajnóczi] Budapest Régiségei 22 (1998) 365-366. Architecture professional commemoration: Hajnóczi Gyula. Épités- Épitészettudomány 26 (1996-1997) 3-4. 199-206.
} 


\section{HAJNÓCZI GYULA AZ OKTATÓ, A TANÁR}

\section{Összefoglaló}

Hajnóczi Gyula születésének századik évfordulójára konferencia keretében emlékezünk az építészre, a régészre, a tanárra, a szakíróra, a tudósra, illetve az emberre, a kollégára. Ezúttal az építészettörténet tanárára, a tanszéki munkatársra emlékezve felvázoljuk az ő tanárainak sorát pályakezdésének idejéből, a sors és rendszerfordító időkből. Szaktudománya, az ókori építészettörténet választása határozott irányt vett már müködése elején. Építészmérnöki oklevele mellé hamar megszerezte a régészdiplomát, a tudományos címeket és a szakírói eredményeket. Oktatóként az építész szakma elejét, az építészeti rajztudást és a szakmatörténetet kidolgozott elvek alapján és változatosan közvetítette a hallgatók felé, az építészeti felmérés, a szerkesztés és a rajzi kidolgozás lépcsői szerint. Az ókori építészetről szóló - Elő Ázsia, Egyiptom, Hellasz, Róma - előadásai mindig egy kidolgozott rendszer szerint, logikus szerkezetben és mindig élvezhető formában hangzottak el. Alapelve volt, hogy az építészet a tovább építés tudománya.

Kulcsszavak: Hajnóczi Gyula, 100. évforduló, építész, ókoros régész, építészettörténész, műemlékvédő

Open Access statement. This is an open-access article distributed under the terms of the Creative Commons Attribution 4.0 International License (https://creativecommons.org/licenses/by/4.0/), which permits unrestricted use, distribution, and reproduction in any medium, provided the original author and source are credited, a link to the CC License is provided, and changes - if any - are indicated. (SID_1)

Received: 7 April 2020. Accepted: 9 April 2020

First published online: 14 October 2020 